\title{
Profile of Osteomyelitis Patients Visiting the Orthopedic Clinic of Dr. Hasan Sadikin General Hospital, Indonesia, in 2017-2018
}

\author{
Aditya Nugraha, ${ }^{1}$ Hermawan Nagar Rasyid, ${ }^{2}$ Hadyana Sukandar ${ }^{3}$ \\ ${ }^{1}$ Faculty of Medicine Universitas Padjadjaran, Indonesia, ${ }^{2}$ Department of Orthopedic \\ and Traumatology Faculty of Medicine Universitas Padjadjaran/Dr. Hasan Sadikin \\ General Hospital Bandung, Indonesia, ${ }^{3}$ Department of Pulic Health Faculty of Medicine \\ Universitas Padjadjaran, Indonesia
}

\section{Abstract}

Background: Osteomyelitis is an inflammatory process caused by microorganism infection that leads to bone destruction. Osteomyelitis may affect all bones, particularly long bones, and infects all ages. This disease is hard to diagnose and the treatment is complex due to the disease's heterogenicity, pathophysiology, clinical presentation, and management. This study aimed to determine the profile of osteomyelitis inpatients and outpatients presented to the Orthopedic Clinic of Dr. Hasan Sadikin General Hospital Bandung, Indonesia.

Methods: This was a descriptive cross-sectional study conducted from July to October 2019 using the total sampling method. Data were collected from the medical records of osteomyelitis inpatients and outpatients presented to the Orthopedic Clinic of Dr. Hasan Sadikin General Hospital Bandung, Indonesia from 2017-2018. Data were then analyzed descriptively and the results were presented in frequencies.

Results: In total, 90 data were retrieved. Most of data presented male patients $(n=69,76.7 \%)$ with the age range of 20-29 years old (24.4\%). The majority of these patients experienced chronic onset of disease (94.4\%) located on the tibia (51.1\%), which was caused by a post-operative procedure $(61.1 \%)$. The most common treatment was operative procedure without antibiotic beads $(51.1 \%)$. Staphylococcus aureus was the common pathogens identified in these patients $(22.2 \%)$.

Conclusions: The majority of osteomyelitis patients are males in productive age with chronic onset of disease located on the tibia caused by a post-operative procedure. Staphylococcus aureus is the common pathogen involved and the most common treatment is an operative procedure without antibiotic beads..

Keywords: Infection, osteomyelitis, Staphylococcus aureus

\section{Introduction}

Osteomyelitis is an inflammation process followed by bone damage and caused by infecting microorganisms. ${ }^{1}$ Osteomyelitis can infect all bones especially long bones and attacks all ages. ${ }^{1}$ Osteomyelitis is an infectious disease that is hard to diagnose and has a complex treatment because of its diversity, pathophysiology, clinical manifestation, and treatment. $^{2,3}$ Infection can be spread from adjacent tissues, through blood, or direct inoculation of bacteria inside the bones as a result of trauma or operation. ${ }^{4,5}$ Clinical manifestation in the osteomyelitis patients shows unspecific symptoms, ${ }^{6}$ therefore, supporting examination is needed such as tissues sampling, radiological imaging, and lab examination. ${ }^{7,8}$

This research used classifications by Lew and Waldvogel. ${ }^{9}$ Based on the disease onset, osteomyelitis is classified as acute and chronic; whereas the source of infection is classified as hematogenic, infection from adjacent tissues and direct inoculation of bacteria inside the bones as a result of trauma or operation., ${ }^{9,10}$ Staphylococcus aureus is the most common bacteria found in osteomyelitis cases. ${ }^{2}$ Depends on the patient's condition and the course of the disease, the type of bacteria can be one or several types of bacteria in the lesion. ${ }^{3}$ An effective management for osteomyelitis is

Correspondence: Aditya Nugraha, Faculty of Medicine Universitas Padjadjaran, Jalan Raya Bandung Sumedang Km. 21 Jatinangor, Sumedang Indonesia, Email: adtngrh@gmail.com 
to diagnose as early as possible and to treat aggressively through debridement and the proper use of antibiotics. ${ }^{11}$

The incidence of osteomyelitis in the United States ${ }^{4}$ is 21.8 cases per 100,000 people per year. Osteomyelitis cases are more common in males than in the females. ${ }^{4}$ There is no clear data for the incidence rate in Indonesia until today. A study in Semarang ${ }^{12}$ has found that of the patients with chronic osteomyelitis, the male is more common. Previous study in Bandung ${ }^{13}$ found that the most prevalent age among chronic osteomyelitis patients is in the range of 17-25 years.

Osteomyelitis is still a problem in the health sector, especially in developing countries including Indonesia. Osteomyelitis requires quite difficult treatment, large fee, long time, complications that often occur especially in chronic cases. Furthermore, a high number of open fractures is not well treated. Therefore, the researchers were interested to explore the general characteristic of osteomyelitis patients at Dr. Hasan Sadikin General Hospital Bandung, in light to improve the awareness of health professionals on osteomyelitis and to further prevent complications.

\section{Methods}

This was a descriptive cross-sectional study conducted from July to October 2019, with a total sampling method. The data were collected from medical records of osteomyelitis inpatients and outpatients in the Department of Orthopedic in Dr. Hasan Sadikin General Hospital Bandung from 2017-2018.

The exclusion criteria were osteomyelitis with infection locations other than the femur, humerus, and tibia. Incomplete or missing medical record data were also excluded. The research was conducted after obtaining approval from the Research Ethics Committee of Universitas Padjadjaran, no. 87/UN6.KEP/ EC/2019, and research permit by the Ethics Training and Committee of Dr. Hasan Sadikin General Hospital, Bandung.

Data on age, gender, disease onset, infection location, given therapy, infection mechanism, the microorganism that caused the infection, and the length of time from the operation history or trauma to the emergence of infection were gathered. Age was measured from the birth year of the individual to the time of the first treatment. Disease onset was categorized as acute and chronic. Acute was defined as infection under 6 weeks and chronic was defined as infection later than 6 weeks.
Infection location was categorized in the femur, humerus, or tibia bones. The therapy given was categorized into conservative and operative treatment. Conservative treatment was defined when the oral antibiotic was given; whereas operative treatment was defined as a treatment that required a surgical procedure. The operative treatment was distinguished by the use of antibiotic beads. Then the length of time was the duration from the last operative treatment until the patients diagnosed with osteomyelitis, and categorized based on less than eight weeks, 8-16 weeks, and more than 16 weeks from the history of the last medical procedure.

\section{Results}

In total, 90 data of osteomyelitis patients were included. The characteristics of the patients were presented in Table 1 , showing that the patients were mostly male $(76.7 \%)$. The average age of the osteomyelitis patients was 32.51 years old (s.d 17.8 years), ranging from 1 to 71 years old, however, the most often age is in the age group of 20-29 years (24.4\%) and had chronic onset $(94.4 \%)$. The location of infection was in the tibia bone $51.1 \%$.

Based on the onset of disease, acute cases most often occurred in males $(80 \%)$, in the age range of 1-9 years old $(80 \%)$, with the infection location in the femur bone (60\%). Hematogenous was the most frequent cause $(80 \%)$, and the chosen therapy was conservative $(60 \%)$ with the microorganism that caused the infection was gram-positive cocci $(67 \%)$. On the other side, based on the chronic cases most often occurred in male (74\%), slightly in the older age range of 20-29 years $(26 \%)$, with the infection location in the tibia bone (52\%), infection mechanism caused by the post-operative (64\%). The chosen therapy was operative without using antibiotic beads $(52 \%)$, and the microorganism found in this study was mostly Staphylococcus aureus (43\%), followed by Pseudomonas aeruginosa, Klebsiella pneumoniae, Staphylococcus epidermidis, and Proteus mirabilis.

Based on gender, osteomyelitis cases in male most often had a chronic onset (94\%), the age range of 20-29 years old (28\%), with infection location in the tibia bone (51\%), and post-operative was the most frequent cause (59\%). The chosen therapy was operative without antibiotic beads (49\%), and the microorganism that caused the infection was Staphylococcus aureus (47\%). In the female, most often had a chronic onset (95\%), the 
Table 1 Demographic Characteristics of Osteomyelitis patients from Dr. Hasan Sadikin General Hospital year 2017-2018

\begin{tabular}{|c|c|c|}
\hline Variable & Total & $\%$ \\
\hline \multicolumn{3}{|l|}{ Gender } \\
\hline Male & 69 & 76.7 \\
\hline Female & 21 & 23.3 \\
\hline \multicolumn{3}{|l|}{ Age (years old) } \\
\hline $1-9$ & 8 & 8.9 \\
\hline $10-19$ & 15 & 16.7 \\
\hline $20-29$ & 22 & 24.4 \\
\hline $30-39$ & 12 & 13.3 \\
\hline $40-49$ & 16 & 17.8 \\
\hline $50-59$ & 10 & 11.1 \\
\hline$>60$ & 7 & 7.8 \\
\hline \multicolumn{3}{|l|}{ Onset } \\
\hline Acute & 5 & 5.6 \\
\hline Chronic & 85 & 94.4 \\
\hline \multicolumn{3}{|l|}{ Location } \\
\hline Femur Bone & 39 & 43.3 \\
\hline Humerus Bone & 5 & 5.6 \\
\hline Tibia Bone & 46 & 51.1 \\
\hline \multicolumn{3}{|l|}{ Infection Mechanism } \\
\hline Hematogenous & 19 & 21.1 \\
\hline Post-operative & 55 & 61.1 \\
\hline Post-trauma & 16 & 17.8 \\
\hline \multicolumn{3}{|l|}{ Therapy Choice } \\
\hline Conservative & 19 & 21.1 \\
\hline \multicolumn{3}{|l|}{ Operative } \\
\hline Antibiotic beads & 25 & 27.8 \\
\hline Without antibiotic beads & 46 & 51.1 \\
\hline \multicolumn{3}{|l|}{ Microorganism* } \\
\hline Staphylococcus aureus & 20 & 22.2 \\
\hline Gram-positive cocci & 8 & 8.9 \\
\hline Gram-negative bacilli & 19 & 21.1 \\
\hline N/A. & 43 & - \\
\hline
\end{tabular}

Note: *Taken from 47 patients with pus culture results

age range of 40-49 years old (28\%), infection location in the tibia bone (52\%), infection mechanism caused by post-operative $(67 \%)$, the chosen therapy was operative without antibiotic beads (57\%), and microorganism that caused the infection was gram-negative bacilli (54\%).

Based on the infection mechanism, hematogenous was the most often occurred in femur bone $(53 \%)$, and for post-operative was in the tibia bone $31(56 \%)$, whereas for the post-trauma in the femur and tibia bones (44\%). The length of time for the onset of osteomyelitis most often occurred after 16 weeks in patients with a post-operative and post-trauma history.

\section{Discussion}

Osteomyelitis patients in this study are mostly male $(76.7 \%)$, in the age range of $20-29$ years $(24.4 \%)$, and with the chronic onset of disease (94.4\%). The majority have osteomyelitis located on the tibia (51.1\%), caused by the postoperative procedure $(61.1 \%)$, the most common treatment operative procedure without antibiotic beads (51.1\%) and Staphylococcus aureus is the common pathogen $(22.2 \%)$. 
Table 2 Characteristic of Osteomyelitis Patients Based on Onset

\begin{tabular}{|c|c|c|}
\hline \multirow[b]{2}{*}{ Variable } & \multicolumn{2}{|c|}{ Onset } \\
\hline & $\begin{array}{c}\text { Acute }(n=5) \\
n(\%)\end{array}$ & $\begin{array}{c}\text { Chronic }(n=85) \\
n(\%)\end{array}$ \\
\hline \multicolumn{3}{|l|}{ Gender } \\
\hline Male & $4(80)$ & $65(74)$ \\
\hline Female & $1(20)$ & $20(24)$ \\
\hline \multicolumn{3}{|l|}{ Age (years old) } \\
\hline $1-9$ & $4(80)$ & $4(5)$ \\
\hline $10-19$ & $1(20)$ & $14(16)$ \\
\hline $20-29$ & 0 & $22(26)$ \\
\hline $30-39$ & 0 & $12(14)$ \\
\hline $40-49$ & 0 & $16(19)$ \\
\hline $50-59$ & 0 & $10(12)$ \\
\hline$>60$ & 0 & $7(8)$ \\
\hline \multicolumn{3}{|l|}{ Location } \\
\hline Femur Bone & $3(60)$ & $36(42)$ \\
\hline Humerus Bone & 0 & $5(6)$ \\
\hline Tibia Bone & $2(40)$ & $44(52)$ \\
\hline \multicolumn{3}{|l|}{ Infection Mechanism } \\
\hline Hematogenous & $4(80)$ & $15(18)$ \\
\hline Post-operative & $1(20)$ & $54(64)$ \\
\hline Post-trauma & 0 & $16(19)$ \\
\hline \multicolumn{3}{|l|}{ Therapy Choice } \\
\hline Conservative & $3(60)$ & $16(19)$ \\
\hline \multicolumn{3}{|l|}{ Operative } \\
\hline Antibiotic beads & 0 & $25(29)$ \\
\hline Without antibiotic beads & $2(40)$ & $44(52)$ \\
\hline \multicolumn{3}{|l|}{ Microorganism* } \\
\hline Staphylococcus aureus & $1(33)$ & $19(43)$ \\
\hline Gram-positive cocci & $2(67)$ & $6(14)$ \\
\hline Gram-negative bacilli & 0 & $19(43)$ \\
\hline N/A. & 2 & 41 \\
\hline
\end{tabular}

Note: *Taken from 47 patients with pus culture results

Based on the results above, the ratio of cases between males and females is $3: 1$. This result is in accordance with the research conducted in Spain, ${ }^{1}$ as well as a previous study in Bandung. ${ }^{13}$ However, there is no significant difference in the general description of osteomyelitis between males and females. The only difference is that the most frequent age range of osteomyelitis in a female is in the age range of 40-49 years old (28\%). The higher incidence of osteomyelitis in males than in females can be caused by the high cases of trauma, causing the bone fracture that is not treated properly as proved by the rates of traffic accident occurred most often in males. ${ }^{14}$

Total patients with chronic onset of osteomyelitis (94.4\%) are higher than the acute cases. Osteomyelitis with chronic onset most often occurred in the age range of 20-29 $(26 \%)$, with an infection mechanism caused by post-operative (64\%), and occurred in the tibia bone (52\%). Interestingly, research conducted in the United States of America (USA) has shown that osteomyelitis most often occurred due to diabetes mellitus disease in the USA, in the age range of 50-59 years old. ${ }^{4}$ Osteomyelitis with acute onset most often occurred in the age range of one to nine years old $(80 \%)$, caused by the spread of infection hematogenously (80\%), and most often occurred in the femur bone (60\%). This result is in accordance with the research conducted 
Table 3 Characteristic of Osteomyelitis Patients Based on Gender

\begin{tabular}{|c|c|c|}
\hline \multirow[b]{2}{*}{ Variable } & \multicolumn{2}{|c|}{ Gender } \\
\hline & $\begin{array}{c}\text { Male }(n=69) \\
n(\%)\end{array}$ & $\begin{array}{c}\text { Female }(n=21) \\
n(\%)\end{array}$ \\
\hline \multicolumn{3}{|l|}{ Onset } \\
\hline Acute & $4(6)$ & $1(5)$ \\
\hline Chronic & $65(94)$ & $20(95)$ \\
\hline \multicolumn{3}{|l|}{ Age (years old) } \\
\hline $1-9$ & $6(9)$ & $2(10)$ \\
\hline $10-19$ & $10(14)$ & $5(24)$ \\
\hline $20-29$ & $19(28)$ & $3(14)$ \\
\hline $30-39$ & $8(12)$ & $4(19)$ \\
\hline $40-49$ & $10(14)$ & $6(28)$ \\
\hline $50-59$ & $9(13)$ & $1(5)$ \\
\hline$>60$ & $7(10)$ & 0 \\
\hline \multicolumn{3}{|l|}{ Location } \\
\hline Femur Bone & $31(45)$ & $8(38)$ \\
\hline Humerus Bone & $3(4)$ & $2(10)$ \\
\hline Tibia Bone & $35(51)$ & $11(52)$ \\
\hline \multicolumn{3}{|l|}{ Infection Mechanism } \\
\hline Hematogenous & $13(19)$ & $6(28)$ \\
\hline Post-operative & $41(59)$ & $14(67)$ \\
\hline Post-trauma & $15(22)$ & $1(5)$ \\
\hline \multicolumn{3}{|l|}{ Therapy Choice } \\
\hline Conservative & $12(17)$ & $7(33)$ \\
\hline \multicolumn{3}{|l|}{ Operative } \\
\hline Antibiotic beads & $23(34)$ & $2(10)$ \\
\hline Without antibiotic beads & $34(49)$ & $12(57)$ \\
\hline \multicolumn{3}{|l|}{ Microorganism* } \\
\hline Staphylococcus aureus & $17(47)$ & $3(27)$ \\
\hline Gram-positive cocci & $6(17)$ & $2(18)$ \\
\hline Gram-negative bacilli & $13(36)$ & $6(54)$ \\
\hline N/A. & 33 & 10 \\
\hline
\end{tabular}

Note: *Taken from 47 patients with pus culture results

Table 4 Description of Location and Length of Time Based on Infection Mechanism

\begin{tabular}{lccc}
\hline \multirow{2}{*}{ Variable } & \multicolumn{3}{c}{ Infection Mechanism } \\
\cline { 2 - 4 } & $\begin{array}{l}\text { Hematogenous }(\mathbf{n = 1 9 )} \\
\mathbf{n ( \% )}\end{array}$ & $\begin{array}{c}\text { Post-operative (n=55) } \\
\mathbf{n ( \% )}\end{array}$ & $\begin{array}{c}\text { Post-trauma (n=16) } \\
\mathbf{n ( \% )}\end{array}$ \\
\hline Location & & & \\
$\quad$ Femur Bone & $10(53)$ & $22(40)$ & $7(44)$ \\
Humerus Bone & $1(5)$ & $2(4)$ & $2(12)$ \\
Tibia Bone & $8(44)$ & $31(56)$ & $7(44)$ \\
Length of time & & & \\
<8 weeks & - & $2(4)$ & $2(12)$ \\
8-16 weeks & - & $42(20)$ & $2(12)$ \\
$>16$ weeks & - & & $12(76)$ \\
\hline
\end{tabular}


in Italy ${ }^{15}$, showing that the acute cases usually happened in children under five years old with hematogenous infection mechanism and most often occurred in the lower extremity.

The infection location in the osteomyelitis patients most often occurrs in the tibia bone (51.1\%) through a post-operative mechanism (56\%). In contrary to a study conducted in the $\mathrm{USA}^{4}$, the most common location for osteomyelitis is the tarsal and metatarsal bones, followed by long bones such as the tibia. The most common cause of osteomyelitis in that research is diabetes mellitus, which causes the degradation of vascular function on the legs. ${ }^{4}$ Similar to research conducted in Spain that shows tarsal and metatarsal as the most common infection location. ${ }^{1}$ Unfortunately, this study does not include patients with the infection location in the tarsal and metatarsal bones and look for data of blood glucose level.

The infection mechanism is most often postoperative $(61.1 \%)$. The osteomyelitis incident most often occurred after 16 weeks from the last medical procedure $(76 \%)$ and occurred in the lower extremity (96\%). Most patients have experienced both open and closed fractures. Interestingly, some patients insisted on going home, and the rest of them are not compliant to exercise control after medical treatment. The infection happened after the medical treatment is highly related to the patient compliance level, leading to high post-operative osteomyelitis incidents in this research. ${ }^{16}$ One of the risk factors that can cause infection after the medical treatment is the biofilm layer attached to the fixation implants. ${ }^{16}$ The most common location for osteomyelitis caused by post-operative is the lower extremities. ${ }^{16,17}$ Interestingly, osteomyelitis most often occurrs in patients with an operation history of under two weeks. ${ }^{16,17}$ One of the factors of the reason why this happens is that probably the way of Indonesian society in seeking treatment, therefore, a patient needs more time to get medical treatment.

The chosen treatment most often performed is the debridement operative procedure without using antibiotic beads (46\%). This procedure is performed in the chronic cases $(52 \%)$ compared to the acute cases $(40 \%)$. This data is in line with others studies resulting in that surgical management most often done in patients diagnosed with chronic osteomyelitis as a debridement procedure. .11,18 $^{11}$ Debridement is very widely used for cases of chronic osteomyelitis, however, the operative procedure does not always solve the problem of this disease. Therefore, comprehensive approach is needed to give the best therapy for patients. ${ }^{2,11}$

Of the 90 patients recruited, there are only $52.2 \%$ patients with pus culture results, of whom Staphylococcus aureus is the most common microorganism that caused osteomyelitis (42.6\%), followed by gramnegative bacilli (40\%). Staphylococcus aureus is the most common bacteria that caused the infection, as confirmed by some other studies. ${ }^{19,20}$ Staphylococcus aureus can interact with osteoblast to cause the bone infection. ${ }^{10}$

The limitation of this study is that diabetes mellitus has not been taken into account. Further study is needed to explore the correlation of diabetes mellitus in relation to osteomyelitis.

In conclusion, this study shows that the osteomyelitis patients are mostly male at productive age, with the majority of patients come with chronic onset. Osteomyelitis most often occurrs in the tibia bone with a post-operative infection mechanism and has a medical history of operative treatment more than 16 weeks before the occurrence of osteomyelitis. The chosen therapy most often used is an operative procedure without antibiotic beads. Staphylococcus aureus is the microorganism that most often caused osteomyelitis.

\section{References}

1. Prieto-pérez L, Pérez-tanoira R, Petkovasaiz E, Pérez-jorge $C$, Lopez-rodriguez $C$, Alvarez-alvarez B, et al. Osteomyelitis: a descriptive study. Clin Orthop Surg. 2014;6(1)20-5.

2. Taki H, Krkovic M, Moore E, Abood A, Norrish A. Chronic long bone osteomyelitis: diagnosis, management and current trends. Br J Hosp Med (Lond). 2016;77(10):C161-4.

3. Calhoun JH, Manring MM, Shirtliff $M$. Osteomyelitis of the long bones. Semin Plast Surg. 2009;23(2):59-72.

4. Kremers HM, Nwojo ME, Ransom JE, Wood-Wentz CM, Melton $3{ }^{\text {rd }}$ LJ, Huddleston $3^{\text {rd }} P M$. Trends in the epidemiology of osteomyelitis a population-based study, 1969 to 2009. J Bone Joint Surg Am 2015;97(10):837-45.

5. Rightmire E, Zurakowski D, Vrahas M. Acute infection after fracture repair; management with hardware in place. Clin Orthop Relat Res. 2008;466(2):466-72.

6. Panteli M, Giannoudis PV. Chronic osteomyelitis: what the surgeon needs to 
know. EFORT Open Rev. 2017;1(5):12835.

7. Solomon L, Warwick DJ, Nayagam S. Apley's and Solomon's concise system of orthopaedics and trauma. 4th ed. Boca Raton: CRC Press; 2014

8. Michno A, Nowak A, Królicki L. Review of contemporary knowledge of osteomyelitis diagnosis. World Scientific News. 2018;92(2):272-82.

9. Lew, DP, Waldvogel F. Osteomyelitis. Lancet. 2004;364(9431):369-79.

10. Roy M, Somerson JS, Kerr KG, Conroy JL. Pathophysiology and pathogenesis of osteomyelitis. In: Baptista MS, editor. Osteomyelitis. London: IntechOpen; 2012 [cited 2019 May 11] Available from: https://www.intechopen.com/books/ osteomyelitis/pathophysiology-andpathogenesis

11. Lima ALL, Oliveira PR, Carvalho VC, Cimerman S, Savio E; Diretrizes Panamericanas para el Tratamiento de las Osteomielitis e Infecciones de Tejidos Blandos Group. Recommendations for the treatment of osteomyelitis. Braz J Infect Dis. 2014;18(5):526-34.

12. Albertus AW, Sutejo B. Pengelolaan pasien osteomielitis kronis di RSUP Dr . Kariadi Semarang Periode 2001-2005 [Minor thesis]. Semarang; Dipenogoro University; 2007 [cited 2019 May 11]. Available from: http://eprints.undip.ac.id/22318/1/ Albertus.pdf

13. Indira SA, Lokarjana L, Pohan DK. Gambaran pasien osteomielitis kronis di Bagian Bedah Orthopaedi RSUP Dr. Hasan Sadikin Bandung Periode Januari
2011-Desember 2016 [minor thesis] Cimahi: Universitas Jenderal Ahmad Yani; 2017 [cited 2019 May 11]. Available from: http://repository.unjani.ac.id/index. php?p=show_detail\&id=375

14. Angela ZA, Tomuka DCh, Siwu J. Pola luka pada kasus kecelakaan lalu lintas di BLU RSU Prof. Dr. R. D. Kandou Manado periode 2010-2011, e-Biomedik (eBM). 2013;1(1):676-85.

15. Chiappini E, Camposampiero C, Lazzeri $\mathrm{S}$, Indolfi $\mathrm{G}, \mathrm{De}$ Martino $\mathrm{M}$, Galli $\mathrm{L}$. Epidemiology and management of acute haematogenous osteomyelitis in a tertiary paediatric center. Int J Environ Res Public Health. 2017;14(5):477.

16. Aytaç S, Schnetzke M, Swartman B, Herrmann P, Woelfl C, Heppert V, et al. Posttraumatic and postoperative osteomyelitis: surgical revision strategy with persisting fistula. Arch Orthop Trauma Surg. 2014;134(2):159-65.

17. Hagen R. Osteomyelitis after operative fracture treatment: a report of 62 cases treated with radical surgery and lincomycin ( Lincocin $\AA$ ). Acta Orthop Scand. 1978;49(6):542-548.

18. Rasyid HN. Konsep baru dalam pembuatan beads mengandung campuran antibiotik dan polymethylmethacrylate untuk terapi osteomielitis kronis [dissertation]. Bandung: Universitas Padjadjaran; 2006.

19. Carek PJ, Dickerson LM, Sack JL. Diagnosis and management of osteomyelitis. Am Fam Physician. 2001;63(12):2413-20.

20. Groll ME, Woods T, Salcido R. Osteomyelitis: a context for wound management. Adv Ski Wound Care. 2018;31(6):253-62. 